\title{
Gender Discrimination in the Media of Eastern Europe: A Historical and Comparative Aspect
}

\author{
Olga Khamedova', Oksana Zhuravska ${ }^{2}$, Olena Rosinska ${ }^{3}$ \& Vitaliy Gandziuk 4 \\ ${ }^{1}$ Assoc. Prof., Dep. of Journalism Institute, Borys Grinchenko Kyiv University, Ukraine, \\ o.khamedova@kubg.edu.ua, https://orcid.org/oooo-0oo2-9545-4464 \\ ${ }^{2}$ Assoc. Prof., Dep. of Journalism Institute, Borys Grinchenko Kyiv University, Ukraine, \\ o.zhuravska@kubg.edu.ua, https://orcid.org/oooo-0oo2-4623-8933 \\ 3 Assoc. Prof., Dep. of Journalism Institute, Borys Grinchenko Kyiv University, Ukraine, \\ o.rosinska@kubg.edu.ua, https://orcid.org/oooo-ooo3-446o-o668 \\ ${ }_{4}^{4}$ Assoc. Prof., Dep. of Journalism Institute, Borys Grinchenko Kyiv University, Ukraine, \\ v.handziuk@kubg.edu.ua, https://orcid.org/oooo-00o2-4312-6848
}

\begin{abstract}
The research analyzes a topical issue of gender balance in media in its historical cutoff. The authors consider imbalance regarding the gender of the key figures in publications as one of indicators of latent discrimination. The subject of the content-analysis is Globus, an illustrated magazine published in Kyiv in 1923-1935. This progressive periodical paid significant attention to the issue of female emancipation; that is why its research is also demonstrative for studying the diachrony of a gender stereotypization phenomenon. The purpose of the content analysis was to determine the qualitative indicators with respect to distribution between verbal and visual women's and men's images in this magazine as a material indicator of worldview stereotypization. As the research results show, Globus had extremely low rate concerning the women's representation in text materials (15\%) and illustrations (18\%). Correspondingly, the ratio of women's and men's images in total amounts to 1:5. Moreover, a tendency to gender asymmetry in 1930's only increased, since the quantity of men's representations in the magazine of 1932 reached almost 90\% and women's ones decreased respectively. Thus, the comparison of women's and men's images already amounted to 1:7, i.d. gender disproportion grew up. The data received have been compared with the monitoring results of current media content related to the compliance with gender balance; that allowed specification and analysis of main tendencies in representation of women and men in the media discourse in the beginning of XX and XXI centuries.
\end{abstract}

Keywords: media representations, content analysis, gender balance, gender discrimination.

\section{Introduction}

The issue of gender balance remains topical in the current media scene. According to the last monitoring study concerning gender balance in the Ukrainian online media performed by NonGovernmental Organization of The Institute of Mass Information in December 2019, women are the key figures in media publications four times rarer than men: $26 \%$ of women against $74 \%$ of men. The experts studied the content of 17 country-wide Internet-media: obozrevatel.com, segodnya.ua, 24tv.ua, tsn.ua, strana.ua, pravda.com.ua, rbc.ua, unian.com, gordonua.com, nv.ua, liga.net, ukrinform.ua, interfax.com.ua, censor.net.ua, tyzhden.ua, znaj.ua, dt.ua. The sample amounted to (C) AesthetixMS 2021. This Open Access article is published under a Creative Commons Attribution Non-Commercial 4.0 International License (http://creativecommons.org/licenses/by-nc/4.o/), which permits non-commercial re-use, distribution, and reproduction in any medium, provided the original work is properly cited. For citation use the DOI. For commercial re-use, please contact editor@rupkatha.com. 
1,700 pieces of news (100 pieces from each media under research taken simultaneously, in December 2019) (Gender balance monitoring in Ukrainian online media, 2019).

The results of identical monitoring performed under Global Media Monitoring based on Myanmar's media sources demonstrate the following: representation in news of men - 80\%, women - 16\%, visual images: men - 65\%, women - 35\% (Breaking Gender Stereotypes, 2020).

In press, gender discrimination can be detected through the use of sexist expressions, emphasis on people's sex rather on their professional achievements or facts in biography, linguistic androcentrism (absence of feminine gender-specific job titles). However, in public discourses, particularly, media ones, gender imbalance and discrimination are rather covert than overt. Covert gender discrimination is determined as "formally neutral rules, criteria or practice, which put defacto a person or persons of a particular group to a disadvantage, in comparison with others" (Gender covert discrimination, 2019). The covert discrimination in press is seen in gender imbalance when choosing key figures or experts for publications among men or women, author's intentionality, in a strategy of a particular media resource in general. The monitoring results demonstrate gender imbalance in current media despite significant achievements of the Ukrainian feminist movement and essential changes in the national gender policy. The reasons and sources of this phenomenon should be sought in the history of press, which has passed a long way to implementation of gender-sensitive journalism principles.

In Ukraine, feminist studies in humanities and social sciences were renewed only in the beginning of 1990s, which is specified by crash of the Soviet Union and the country's exit from the Soviet information scene. However, the history of the movement for women's rights is long. For example, in the western part of Ukraine (Halychyna and Volyn') the Union of the Ukrainian Women (Ukrainian: Soyuz Ukrayinok) - one of the largest women's organizations not only in Ukraine but also in Europe - functioned during 1920 - 1939. According to different estimates, it amounted to 100,000 participants from different social strata and different parties. That was a period of intensive development of the Soviet feminist project and its gradual scrapping; that is why studying periodical press as representation of these processes is quite interesting.

Activation of the Bolshevik feminist project was specified by the authorities' intention to have as many women as possible involved into the revolutionary struggle, to grow them as committed communists dedicated to the Soviet regime, strengthening and establishing it in this way, as well as to create grounds for the world's revolution. That is why in the 1920s, a "Bolshevik's emancipation project" (Voronina, 2017) started: that was a range of measures aimed at integration of women into the social (first of all, party's) life and mass involvement of women into manufacturing. The establishment of women's departments and a post of a women's organizer in party cells of all levels, regular meetings of female deputies, campaigns on engagement of house wives, employees' wives into community work, etc. Thus, the communists took control over the feminist movement, and efforts of public activists were steered on the course right for the party.

In the 1920 s there appeared periodicals for women Communard of Ukraine, Peasant woman of Ukraine, from 1932 - Collective farmer of Ukraine that indicated attention of the party to “women's issue". The leading news magazines (Red Way, Life and Revolution, Culture and Life, etc.) covered the issues of women's social role, importance of marriage and family in compliance with communist ideology, based on the work of classical authors of historical materialism, particularly, on The Origin of the Family, Private Property and The State by F. Engels.

In 1930, the women's departments in party cells were ditched, and disappeared within several years as "women's" issue was declared to be completely solved in the Soviet Union 
(Voronina, 2017). Due to the change of gender policy in the Soviet Union in 1930s, the discussions in press about marriage, family, women's emancipation ceased; however, the themes related to production and manufacturing were under intensive discussion, particularly, a theme of highpowered work. Stalin's words "Women in collective farms are a great power" were a reason for creating numerous texts about female collective farmers in the Republic's press of all levels. The pages of Communard of Ukraine and Peasant woman of Ukraine magazines were full of articles about work achievements of female key figures, but the main issues of women's everyday life, routine and home life were out of attention. That is why it is interesting to analyze the content of the press in that period related to the gender issue dynamically, comparing the content of magazines and newspapers for the 1920 and 1930 .

\section{Methods}

Gender media studies are interdisciplinary and are formed at the intersection of media studies, cultural studies and gender studies. The works by such media researchers as J. Butler (2016), D. Matheson (2017), L. van Zoonen (1994), R. Gill (2009), D. McQuail (2010), M. Lazar (2007) prove that. In our opinion, the feminist criticism remains a leading method and an interpretative strategy, as the media texts are analyzed mostly from its positions; although, if required, the researchers involve the instruments of psychoanalysis, semiotics, as well as a quantitative analysis traditional for mass media. D. McQuail shares this opinion specifying "literature, discourse and psychoanalysis methods" (McQuail, 2010) as the most popular.

L. van Zoonen, the author of Feminist Media Studies monograph, stressed that the methodology of media gender researchers includes miscellaneous researching method and strategies:

"Methodological purism, however, does not stand much chance in a field that is increasingly distinguished by commonalities rather than differences." (Zoonen, 1994).

Symbolic interactionism proceeds from the premise that the reality is a product of interpretations formed by the interaction of people with others. The key issue is how "people agreed concerning the definition of situations and how these definitions govern their actions and experience" (Zoonen, 1994). In this view, it is topical to study the activity of journalists, media establishments and audience as the one forming a specific worldview of a recipient, creating subconscious attitude to evaluative perception of different phenomena, particularly, journalist's activity on news production was considered as one of reality constructing forms - facts selection ("agenda"), accentuation of details, etc.

Thus, media representation of indirect gender discrimination can also be detected in author's communication intentions through a specific selection and interpretation of facts, or a certain media resource strategy, which immediately influence on recipients and construct their social knowledge, form their worldview. The content author can also be a hostage of their subconscious views concerning an axiological weight of context elements.

While performing a gender analysis of a media text, a researcher faces a problem of a proper, i.e. free from own mind sets and prejudices, interpretation of the text and illustrative materials. The content analysis, owing to which one can study the messages content without prejudice, is traditionally applied to avoid subjectivity of evaluations and judgements. 
One of the first fundamental media researches where the content analysis used to find out gender imbalance in media was the work of Gender Advertisements by an American researcher E. Goffman (1976). The researcher analyzes visual representations of men and women in press and made conclusions concerning stereotyping gender images, found out regularities of male and female images in advertisements. Gender media researchers show a stable interest to the analysis of so called "glossy' magazines with their typology based on the segmentation of readership by gender, i.e. division of the magazines into "women's" and "men's" ones. However, the content analysis method remains leading. In our opinion, the gender content-analysis should be also used to research universal and newsmagazines as they have a wider audience consisting both of men and women.

For gender content-analysis we have chosen Globus, a universal illustrated fortnightly magazine in Ukrainian, published in 1923-1935 in Kyiv. The magazine published interesting and informative articles dedicated to the social issues topical for the Ukrainians living at that time, including women's emancipation; it showed a reliable image of big city's life in its dynamics during the 1920 - the beginning of 1930s. The magazine staff even in the period of the Soviet totalitarianism managed to balance between the readers' interests and the authorities' requirements: they did not publish overtly propagandistic materials so often as other periodicals.

The analysis of the magazine content provides an opportunity to find out a strategic course of the editorial policy and determine key content ideologemes. The purpose of the content analysis was to compile descriptive statistic of women's and men's images (verbal and visual). As sociologists state, "a category of an analysis is a certain analogue of a social problem in a particular research" (Fedotova, 2004). In our research we have worked with such a category of analysis as a "gender identification of the person". Focusing towards particular texts and illustrative materials (photos and figures), we have operated with such a working analysis unit as a "person", i.e. verbal and visual image of a man or a woman.

The context for this analysis of text materials is a particular text of any genre in a magazine where the persons were men and/or women, and the context of illustrative materials - a particular photograph or a picture where men and/or women were depicted. One should clear up that while calculating, text and illustrative materials with available men's and women's images went, correspondingly, into two categories - both men's and women's representations.

During the 1920-1930s fundamental changes in the gender policy of the Soviet regime occurred: from support of emancipatory aspirations of women at the institutional level - until restoration of the patriarchic values system simultaneously strengthening Stalin's autocratic power in the 1920-1930s. For comparative gender analysis there were chosen two annual packages of Globus - for 1925 and 1932, as it was important to show this process in dynamics during the 19201930s. The researches were carried out calculating the amount of materials (individual texts or illustrations) with men's and women's representations, which were computed as a sequence of natural numbers from 1 to $\mathrm{n}$, as well as in percentage.

\section{Result and discussion}

Table I provides data concerning the ratio of men and women represented on the pages of the Ukrainian magazine Globus under research as key figures of the texts and visual materials. The statistics demonstrates large inequality in representation of two sexes; in general, that shows social roles of men and women in the society of that period. 
Table I: The results of the comparative content-analysis of media representation of women and men as persons in Globus, a Ukrainian magazine, for 1925

\begin{tabular}{|c|c|c|c|c|c|c|c|c|c|}
\hline \multirow{3}{*}{$\begin{array}{l}\text { Number, } \\
\text { month }\end{array}$} & & & \multicolumn{4}{|c|}{ GLOBUS MAGAZINE } & \multirow[b]{2}{*}{ men } & \multirow{2}{*}{\multicolumn{2}{|c|}{ women }} \\
\hline & \multicolumn{2}{|r|}{ men } & \multicolumn{2}{|r|}{ women } & \multirow{3}{*}{$\begin{array}{c}\text { Number, } \\
\text { month }\end{array}$} & \multirow{3}{*}{ Text } & & & \\
\hline & Text & Illustration & Text & Illustration & & & Illustration & Text & Illustration \\
\hline & & & & & & & & & \\
\hline $\begin{array}{l}\text { No. } 1 \text { (29) } \\
\text { January }\end{array}$ & $\begin{array}{l}14 \\
82 \%\end{array}$ & $\begin{array}{l}23 \\
82 \%\end{array}$ & $\begin{array}{l}3 \\
18 \%\end{array}$ & $\begin{array}{l}5 \\
18 \%\end{array}$ & $\begin{array}{l}\text { No. } 13(41) \\
\text { July }\end{array}$ & $\begin{array}{l}29 \\
90 \%\end{array}$ & $\begin{array}{l}43 \\
78 \%\end{array}$ & $\begin{array}{l}3 \\
10 \%\end{array}$ & $\begin{array}{l}12 \\
22 \%\end{array}$ \\
\hline $\begin{array}{c}\text { No. } 2 \text { (3o) } \\
\text { January }\end{array}$ & $\begin{array}{l}12 \\
80 \%\end{array}$ & $\begin{array}{l}30 \\
75 \%\end{array}$ & $\begin{array}{l}3 \\
20 \%\end{array}$ & $\begin{array}{l}10 \\
25 \%\end{array}$ & $\begin{array}{l}\text { No. } 14(42) \\
\text { July }\end{array}$ & $\begin{array}{l}16 \\
89 \%\end{array}$ & $\begin{array}{l}33 \\
72 \%\end{array}$ & $\begin{array}{l}2 \\
11 \%\end{array}$ & $\begin{array}{l}13 \\
28 \%\end{array}$ \\
\hline $\begin{array}{l}\text { No.3(31) } \\
\text { February }\end{array}$ & $\begin{array}{l}21 \\
91 \%\end{array}$ & $\begin{array}{l}27 \\
87 \%\end{array}$ & $\begin{array}{l}2 \\
9 \%\end{array}$ & $\begin{array}{l}4 \\
13 \%\end{array}$ & $\begin{array}{c}\text { No. } 15 \text { (43) } \\
\text { August }\end{array}$ & $\begin{array}{l}18 \\
90 \%\end{array}$ & $\begin{array}{l}54 \\
82 \%\end{array}$ & $\begin{array}{l}2 \\
10 \%\end{array}$ & $\begin{array}{l}12 \\
18 \%\end{array}$ \\
\hline $\begin{array}{l}\text { No. } 4(32) \\
\text { February }\end{array}$ & $\begin{array}{l}21 \\
81 \%\end{array}$ & $\begin{array}{l}41 \\
80 \%\end{array}$ & $\begin{array}{l}5 \\
19 \%\end{array}$ & $\begin{array}{l}10 \\
20 \%\end{array}$ & $\begin{array}{c}\text { No. } 16(44) \\
\text { August }\end{array}$ & $\begin{array}{l}18 \\
78 \%\end{array}$ & $\begin{array}{l}45 \\
88 \%\end{array}$ & $\begin{array}{l}5 \\
22 \%\end{array}$ & $\begin{array}{l}6 \\
12 \%\end{array}$ \\
\hline $\begin{array}{c}\text { No. } 5 \text { (33) } \\
\text { March }\end{array}$ & $\begin{array}{l}21 \\
78 \%\end{array}$ & $\begin{array}{l}56 \\
76 \%\end{array}$ & $\begin{array}{l}6 \\
22 \%\end{array}$ & $\begin{array}{l}18 \\
24 \%\end{array}$ & $\begin{array}{l}\text { No. } 17 \text { (45) } \\
\text { September }\end{array}$ & $\begin{array}{l}30 \\
91 \%\end{array}$ & $\begin{array}{l}35 \\
81 \%\end{array}$ & $\begin{array}{l}3 \\
9 \%\end{array}$ & $\begin{array}{l}8 \\
19 \%\end{array}$ \\
\hline $\begin{array}{c}\text { No. } 6(34) \\
\text { March }\end{array}$ & $\begin{array}{l}29 \\
91 \%\end{array}$ & $\begin{array}{l}59 \\
94 \%\end{array}$ & $\begin{array}{l}3 \\
9 \%\end{array}$ & $\begin{array}{l}4 \\
6 \%\end{array}$ & $\begin{array}{l}\text { No. } 18(46) \\
\text { September }\end{array}$ & $\begin{array}{l}14 \\
82 \%\end{array}$ & $\begin{array}{l}35 \\
81 \%\end{array}$ & $\begin{array}{l}3 \\
18 \%\end{array}$ & $\begin{array}{l}8 \\
19 \%\end{array}$ \\
\hline $\begin{array}{c}\text { No. } 7 \text { (35) } \\
\text { April }\end{array}$ & $\begin{array}{l}23 \\
85 \%\end{array}$ & $\begin{array}{l}36 \\
78 \%\end{array}$ & $\begin{array}{l}4 \\
15 \%\end{array}$ & $\begin{array}{l}10 \\
22 \%\end{array}$ & $\begin{array}{l}\text { No. } 19(47) \\
\text { October }\end{array}$ & $\begin{array}{l}25 \\
89 \%\end{array}$ & $\begin{array}{l}38 \\
86 \%\end{array}$ & $\begin{array}{l}3 \\
11 \%\end{array}$ & $\begin{array}{l}6 \\
14 \%\end{array}$ \\
\hline $\begin{array}{c}\text { No. } 8(36) \\
\text { April }\end{array}$ & $\begin{array}{l}25 \\
83 \%\end{array}$ & $\begin{array}{l}45 \\
80 \%\end{array}$ & $\begin{array}{l}5 \\
17 \%\end{array}$ & $\begin{array}{l}11 \\
20 \%\end{array}$ & $\begin{array}{l}\text { No. } 20(48) \\
\text { October }\end{array}$ & $\begin{array}{l}11 \\
100 \%\end{array}$ & $\begin{array}{l}40 \\
93 \%\end{array}$ & - & $\begin{array}{l}3 \\
7 \%\end{array}$ \\
\hline $\begin{array}{c}\text { No. } 9(37) \\
\text { May }\end{array}$ & $\begin{array}{l}14 \\
78 \%\end{array}$ & $\begin{array}{l}45 \\
85 \%\end{array}$ & $\begin{array}{l}4 \\
22 \%\end{array}$ & $\begin{array}{l}8 \\
15 \%\end{array}$ & $\begin{array}{l}\text { No. } 21(49) \\
\text { November }\end{array}$ & $\begin{array}{l}13 \\
87 \%\end{array}$ & $\begin{array}{l}17 \\
85 \%\end{array}$ & $\begin{array}{l}2 \\
13 \%\end{array}$ & $\begin{array}{l}3 \\
15 \%\end{array}$ \\
\hline $\begin{array}{c}\text { No. } 10(38) \\
\text { May }\end{array}$ & $\begin{array}{l}21 \\
81 \%\end{array}$ & $\begin{array}{l}45 \\
83 \%\end{array}$ & $\begin{array}{l}5 \\
19 \%\end{array}$ & $\begin{array}{l}9 \\
17 \%\end{array}$ & $\begin{array}{l}\text { No. } 22(50) \\
\text { December }\end{array}$ & $\begin{array}{l}17 \\
85 \%\end{array}$ & $\begin{array}{l}37 \\
77 \%\end{array}$ & $\begin{array}{l}3 \\
15 \%\end{array}$ & $\begin{array}{l}11 \\
23 \%\end{array}$ \\
\hline $\begin{array}{l}\text { No. 11 (39) } \\
\text { June }\end{array}$ & $\begin{array}{l}18 \\
86 \%\end{array}$ & $\begin{array}{l}34 \\
75 \%\end{array}$ & $\begin{array}{l}3 \\
14 \%\end{array}$ & $\begin{array}{l}11 \\
24 \%\end{array}$ & $\begin{array}{c}\text { No. } 23-24 \\
(50-51) \\
\text { December } \\
932\end{array}$ & $\begin{array}{l}23 \\
88 \%\end{array}$ & $\begin{array}{l}55 \\
90 \%\end{array}$ & $\begin{array}{l}3 \\
12 \%\end{array}$ & $\begin{array}{l}6 \\
10 \%\end{array}$ \\
\hline $\begin{array}{c}\text { No. } 1 \text { (193) } \\
\text { January }\end{array}$ & $\begin{array}{l}12 \\
92 \%\end{array}$ & $\begin{array}{l}19 \\
100 \%\end{array}$ & $\begin{array}{l}1 \\
8 \%\end{array}$ & - & $\begin{array}{c}\text { No. 11-12 } \\
\left(203^{-204}\right) \\
\text { June }\end{array}$ & $\begin{array}{l}21 \\
88 \%\end{array}$ & $\begin{array}{l}19 \\
83 \%\end{array}$ & $\begin{array}{l}3 \\
12\end{array}$ & $\begin{array}{l}4 \\
17 \%\end{array}$ \\
\hline $\begin{array}{c}\text { No. } 2 \text { (194) } \\
\text { January }\end{array}$ & $\begin{array}{l}17 \\
92 \%\end{array}$ & $\begin{array}{l}25 \\
89 \%\end{array}$ & $\begin{array}{l}1 \\
8 \%\end{array}$ & $\begin{array}{l}3 \\
11 \%\end{array}$ & $\begin{array}{c}\text { No. 13-14 } \\
\text { (205-206) } \\
\text { July }\end{array}$ & $\begin{array}{l}16 \\
94 \%\end{array}$ & $\begin{array}{l}21 \\
88 \%\end{array}$ & $\begin{array}{l}1 \\
6 \%\end{array}$ & $\begin{array}{l}3 \\
12 \%\end{array}$ \\
\hline $\begin{array}{c}\text { No. 3-4 } \\
(195-196) \\
\text { February }\end{array}$ & $\begin{array}{l}17 \\
100 \%\end{array}$ & $\begin{array}{l}30 \\
100 \%\end{array}$ & - & - & $\begin{array}{c}\text { No. 15-16 } \\
(207-208) \\
\text { August }\end{array}$ & $\begin{array}{l}13 \\
81 \%\end{array}$ & $\begin{array}{l}15 \\
68 \%\end{array}$ & $\begin{array}{l}3 \\
19 \%\end{array}$ & $\begin{array}{l}7 \\
32 \%\end{array}$ \\
\hline $\begin{array}{c}\text { No. 5-6 } \\
(197-198) \\
\text { March }\end{array}$ & $\begin{array}{l}16 \\
80 \%\end{array}$ & $\begin{array}{l}20 \\
80 \%\end{array}$ & $\begin{array}{l}4 \\
20 \%\end{array}$ & $\begin{array}{l}5 \\
20 \%\end{array}$ & $\begin{array}{l}\text { No. 17-18 } \\
(209-210) \\
\text { September }\end{array}$ & $\begin{array}{l}22 \\
96 \%\end{array}$ & $\begin{array}{l}14 \\
82 \%\end{array}$ & $\begin{array}{l}1 \\
4 \%\end{array}$ & $\begin{array}{l}3 \\
18 \%\end{array}$ \\
\hline $\begin{array}{c}\text { No. 7-8 } \\
\text { (199-20o) } \\
\text { April }\end{array}$ & $\begin{array}{l}20 \\
100 \%\end{array}$ & $\begin{array}{l}21 \\
88 \%\end{array}$ & o\% & $\begin{array}{l}3 \\
12 \%\end{array}$ & $\begin{array}{c}\text { No. 19-2o } \\
(211-212) \\
\text { October }\end{array}$ & $\begin{array}{l}11 \\
79 \%\end{array}$ & $\begin{array}{l}17 \\
71 \%\end{array}$ & $\begin{array}{l}3 \\
21 \%\end{array}$ & $\begin{array}{l}7 \\
29 \%\end{array}$ \\
\hline $\begin{array}{l}\text { No. } 9 \\
(201) \\
\text { May }\end{array}$ & $\begin{array}{l}23 \\
96 \%\end{array}$ & $\begin{array}{l}24 \\
100 \%\end{array}$ & $\begin{array}{l}1 \\
4 \%\end{array}$ & - & $\begin{array}{c}\text { No. 21-22 } \\
(213-214) \\
\text { November }\end{array}$ & $\begin{array}{l}14 \\
82 \%\end{array}$ & $\begin{array}{l}8 \\
80 \%\end{array}$ & $\begin{array}{l}3 \\
18 \%\end{array}$ & $\begin{array}{l}2 \\
20 \%\end{array}$ \\
\hline $\begin{array}{c}\text { No. 10 } \\
(202) \\
\text { June }\end{array}$ & $\begin{array}{l}20 \\
83 \%\end{array}$ & $\begin{array}{l}18 \\
69 \%\end{array}$ & $\begin{array}{l}4 \\
17 \%\end{array}$ & $\begin{array}{l}8 \\
31 \%\end{array}$ & $\begin{array}{c}\text { No. } 23-24 \\
(215-216) \\
\text { December }\end{array}$ & $\begin{array}{l}11 \\
100 \%\end{array}$ & $\begin{array}{l}19 \\
100 \%\end{array}$ & - & - \\
\hline
\end{tabular}


The context for this analysis of text materials is a particular text of any genre in a magazine where the persons were men and/or women, and the context of illustrative materials - a particular photograph or a picture where men and/or women were depicted. One should clear up that while calculating, text and illustrative materials with available men's and women's images went, correspondingly, into two categories - both men's and women's representations.

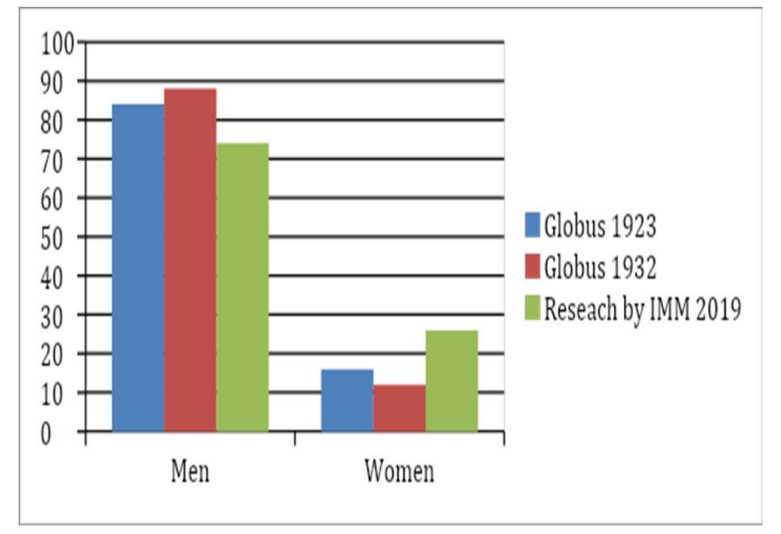

Figure 1: Comparison of female and male images as persons in publications in Globus (1923 and 1932).

The comparison of commensuration results of female and male images as key figures of publications and illustrations is presented relevantly in Figure 1 and Figure 2 where

- Globus 1923 - data of the content-analysis of Globus for 1923;

- Globus 1932 - data of the content-analysis of Globus for 1932;

- Research by IMM - data of monitoring concerning compliance with gender balance performed by Non-Governmental Organization of Institute of Mass Information in December 2019 (Gender balance monitoring in Ukrainian online media, 9).

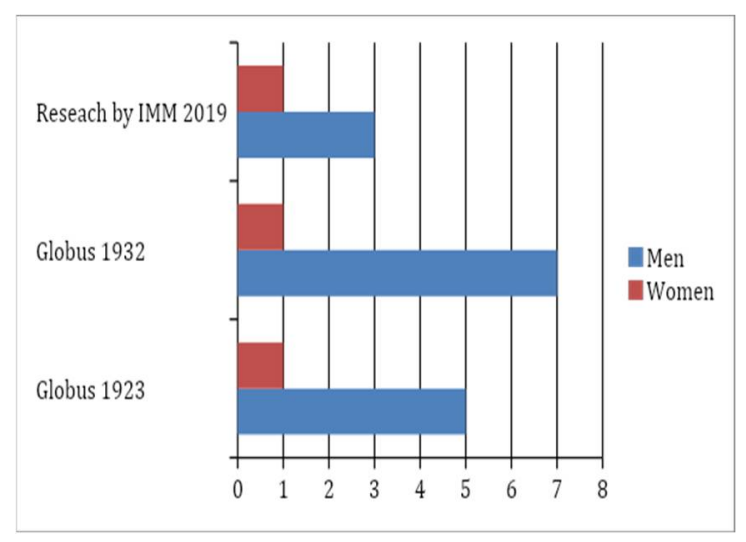

Figure 2: The comparison of female and male images as key figures of publications in Globus (1923 and 1932).

It is indicative that the biggest amount of visual representation of women in Globus falls on the March edition on the eve of March 8, a women's holiday instituted by the Soviet authorities, thus, this indicator is not essential to foreground social role of women. A theme of so called "new routine" related to the women's emancipation was popular in the Ukrainian press in the 1920 . Globus for 1925 discusses a necessity to release the woman from hard work around the house; it announced the creation of a net of nursery schools and kinder gardens, public canteens and 
laundries. It was stressed that the woman could use the time spent on house work for social obligations and learning. The journalists emphasized that an undereducated countrywoman or a worker had to change themselves dramatically to take an active part in social life. That is why the magazine published stories (correspondence, sketches, articles) how a proletarian woman overcame illiteracy, studied, obtained a profession, took part in public events, changed gradually herself, her family and everyday life, and finally, her own awareness. These partially propagandistic texts written in a simple and clear language inspired women to overcome obstacles and gender stereotypes, as well as raised their self-respect.

The 1920-1930s in the USSR were the period of industrializing, the age of large-scale economic experiments and modifications in industry. The implementation of these ambitious plans required a huge number of workers, including women. In the 1920 s the women came massively to plants and factories and strived to obtain a particular qualification, to study, but social superstitions and gender stereotypes impeded. The real condition of the Ukrainian women at the employment market was unsteady and uncertain. That is why it is not surprising that the industrial theme was leading in the Soviet press in the 1920-1930s. In the 1920s, which are traditionally considered after M. Voronina the age of "Bolshevik's emancipation experiment" (Voronina, 2017), the magazine published articles calling to women's emancipation in all the areas of life, to struggle decisively against the demonstrations of gender imbalance at plants/factories and in everyday life.

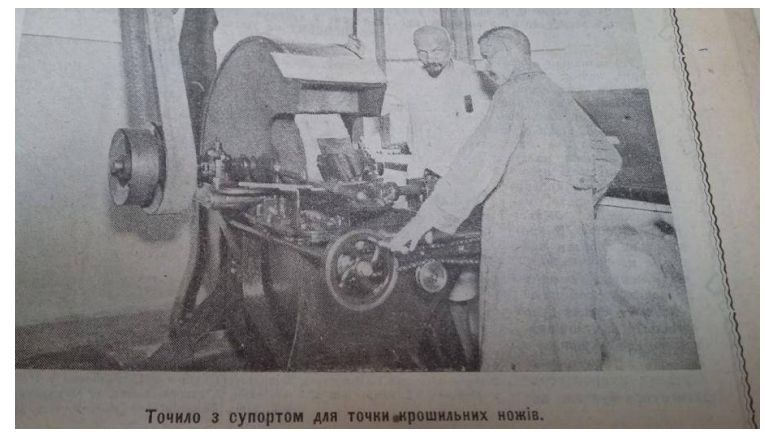

Figure 3: Grinding machine with a saddle for sharpening crumbling knives. Retrieved from Globus (1925, No.3)

Texts and visual materials in Globus both for 1925 and 1932 fixed the roles of women and men in different professional fields: men were involved into manufacturing enterprises (Figure 3) and women - in agriculture (Figure 4).

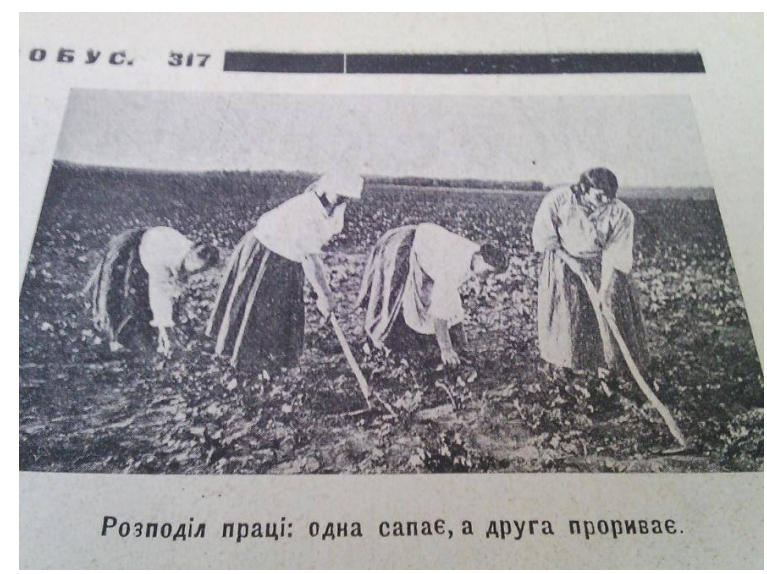

Figure 4: Division of work: one is weeding, one is pulling. Retrieved from Globus (1926, No.15) 
The most prestigious fields were considered mining, metallurgy, construction, i.e. those involving men, in particular. The magazine told about the countrywomen who were involved into field work of the lowest qualification (handwork: weeding, harvest collection by hands, pest control), however, men in collective farms did engine-driven work, which required higher qualification and was better paid (tractor drivers, farm machinery operators). Journalists stated 'horizontal gender segregation" in Soviet Ukraine in 1930s, i.e. "such mechanism of gender distribution, which means the division of the market into so called "female" and "male" professions, which are paid unequally, since "female" professions are the ones paid lower. Historians confirm gender discrimination in labour payment: "From 1930-1931 until the late 1950s the following payment model of collective farmers' work was in force: one day of work in a beetroot field -0.5 workday, for driving a tractor -4.5 workdays" (Voronina, 2017). As publications of 1930 certify, the managerial positions (the Head, an agriculturist, an accountant, etc.) in collective farms were also occupied by men, and the top position for a woman to reach in a collective farm was a team leader or, much more rarely, a forewoman).

However, there are extremely few materials to see the demonstration of gender segregation in the magazine for 1932 in comparison with 1925. The researchers of the Soviet visual culture P. Romanov and Ye. Yarska-Smirnova specifies that any visual artefact (a picture, a placard, a photo) must be read as a message in ideological and cultural contexts:

"any source, including a visual one, is not a direct representation of a real event, but its imprints created by someone for interpretation... That is why, for studying we have the created, virtual reality available" (Romanov, Yarskaya-Smirnova, 2009).

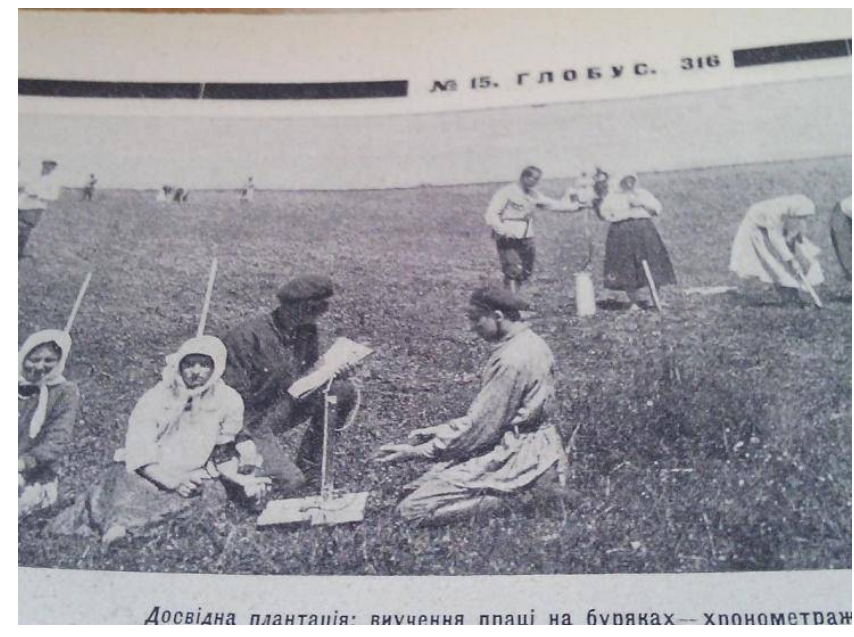

Figure 5: Experimental plantation: teaching how to work on a beetroot field - timestudy. Retrieved from Globus (1926, No.15)

Visual representations of women and men in the magazine spoke volumes about professional discrimination of women, particularly, about such its manifestations as "horizontal" and "vertical" professional segregation. The photos of working staff of that period demonstrate a higher career status of men (Figure 5), the employment of men in complicated engine-driven work, and of women - in the most primitive one (Figure 6; Figure 7). Photo correspondents underlined power position of men concerning women, for example, men-chiefs were snapped in front of female workers in the workshop or posed front and centre with women from the collective farm working in the field at the background). 


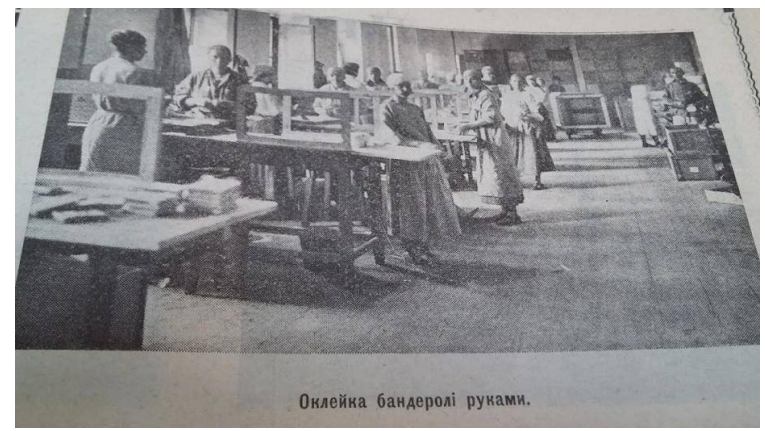

Figure 6: Gluing small parcels manually. Retrieved from Globus (1925, No.15)

This form of napping applied by photo correspondents of that period certified that press constructed a gender worldview and established a gender regime rather than just mirrored social and cultural norms. And if, in O. Sovenko's opinion, "intensity and content-richness of the gender discourse" in modern periodic editions are specified "both by an initiative of editorial staff and its authors and by inquiries of the readers themselves", the gender discourse of newspapers and magazines in the 1920-1930s was mostly formed by a "socialistic order" or the authorities and ideology in force (Sovenko, 2017).

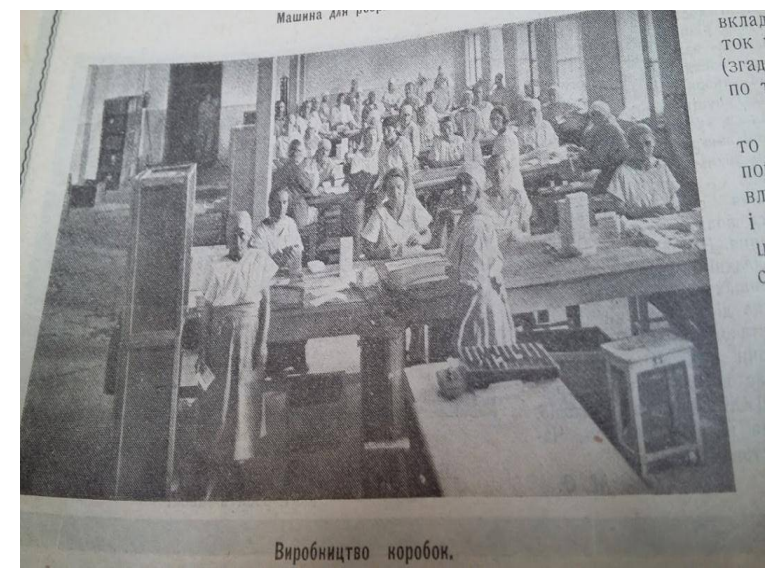

Figure 7: Box making. Retrieved from Globus (1925, No.3)

The amount of figures and photos on a military theme with the Red Army soldiers depicted in the magazine grew up in 1932 compared to 1926. That did not only speak for militarization of the Soviet community, its preparation to the war against capitalist countries but also for the return to the public discourse of a man-combatant ideologeme as a basis of a hegemonic masculinity.

In the Ukrainian press of 1930 it becomes more evident that the women's activity is limited with particular social constraints. Publications about women who reached independently success in work were rare; however, the ideal of a woman as a man's helpmate was cherished, i.e. she was inflicted herself with a subordinate role.

Under the initiative by S. Ordzhonikidze, a People's Commissar of heavy industry, the employee's wives were called to do non-paid service work, for example, to keep clean employee dormitories, to tidy up the territory of a plant or a mine where their husbands work, to control 
workplace discipline of their husbands ("we will achieve the state for no shirker no fly-boy to be in these dormitories") (Malytskyi, 1932).

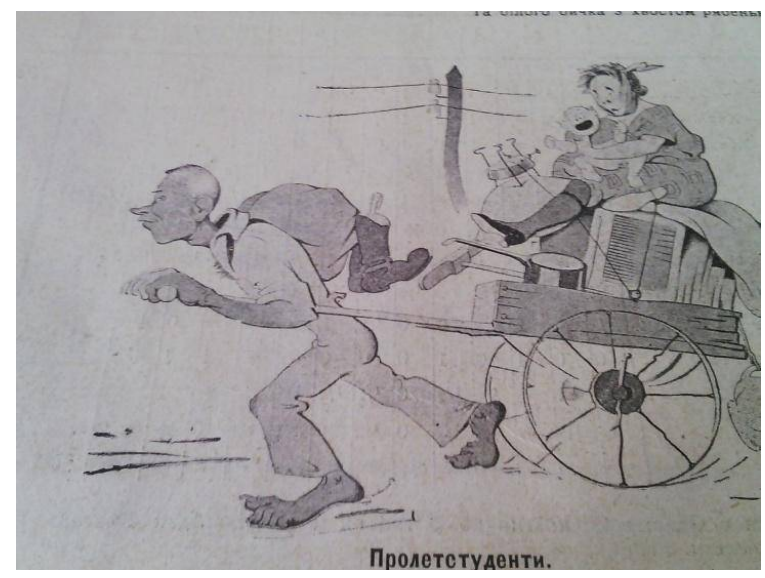

Figure 8: Proletarian students. Retrieved from Globus (1926. No.6)

The materials about women - shock workers were illustrated with their photos at home, among their children, while men-shock workers were always shown working at manufacturing; that created public views about social priorities of women and men (Figure 8). Apart from the declarations about practicability of children's education in collective bodies (nursery schools, kinder gardens, and schools), care about children, their raising remained women's obligations. Many social activists in the interview with the magazine correspondents told proudly that they bred their children as patriots of their country and communists. Thus, in press it was recorded double labour load of the Soviet woman who had to take care about the whole family, to solve domestic problems and simultaneously work "shockingly" at manufacturing, do social work, take part on party's meetings, etc. As the research results certified, in popular magazine of Globus in 1925 there were extremely low indicators of women's representations $-15 \%$ (men - 85\%) in text materials, and $18 \%$ (men $-82 \%)$ - in illustrative ones. Correspondingly, in total, ratio of male and female images amounts to $1: 5$.

Moreover, the tendency to gender asymmetry in 1930 os only strengthened since the quantity of "male" materials (both visual and text ones) in the magazine of 1932 grew up by $4 \%$ and reached 90\% in text materials and 86 in visual ones, and "women's" part decreased correspondingly by $4 \%$ and amounted to $10 \%$ of text and $14 \%$ of visual representations. Thus, in 1932 the ratio of female and male images was 1:7. That means that gender disproportion increased. Has the situation with women's representation as persons changed for better in the modern Ukrainian press? For comparison one may provide the results of gender monitoring of current Ukrainian mass-media for 2018, which sociologist O. Sovenko called “shocking disproportion between men's and women's images in media (3 tol correspondingly, or 4 to 1 )".

\section{Conclusions}

Hence, the gender content analysis of Globus demonstrated both overt and covert gender discrimination of women. The materials published by the magazine in 1925 and dedicated to professional implementation and social self-implementation of women, issues of women's 
education, women's unemployment, etc., certify that. The publications recorded the demonstrations of gender discrimination in the professional area; particularly, it was about "vertical" and "horizontal" gender segregation which did not allow a woman's professional selfimplementation. The issues of professional discrimination of the Ukrainian women were depicted mostly within the columns dedicated to women and "women's issue"; in such a way the theme was segregated and defined as topical only for this subordinate group, not only for the whole society. The fact that more "women's" publications and illustrations appeared in the March issue dedicated to the International Day of Fight for Women's Rights prove absence of a particular strategy of women's movement development in Soviet Ukraine.

Publications for 1932 about labour deeds of female "shocking workers" did not represent the reality objectively but constructed a parallel reality, replicating the stories about wealthy and happy life of female collective farmers and workers. In such texts a manipulative component was over powerful, since the readers were being persuaded that over-regular, "shocking" work is the only way to welfare.

Moreover, the comparative content analysis of Globus for 1925 and 1932 also detected latent discrimination of women, since despite some attention to the "women's issue" from the popular Ukrainian fortnightly magazine, especially in the 1920s, the level of women's representation as key figures in publications remained extremely low. In the magazine for 1925 women were mentioned only in $15 \%$ of text materials, compared to $85 \%$ of men, there were $18 \%$ of visual representations of women, and $82 \%$ of men.

A tendency to gender asymmetry increased in the 1930 since the amount of "men's" materials (both visual and text) in magazine of 1932 increased by $4 \%$ and reached 90\% in text materials and 86 in visual ones, and "women's" part decreased, correspondingly, by $4 \%$ and amounted to $10 \%$ of text and $14 \%$ of visual representations. Thus, there was recorded a tendency to a decrease of media representation of women in text and illustrative materials in the 1930s. In the magazine for 1925, the general ratio between female and male images was 1:5. In 1932, the ratio was already 1:7, i.e. gender disproportion increased.

The results received certify that gender discrimination of women took place even in favourable conditions of feminist movement development in 1920. The content analysis of Globus magazine for 1932 confirmed that the period of totalitarianism became for the Soviet Ukrainian women an age of returning to patriarchy. Despite the final solution of "women's issue" declared in 1930 by the communist authorities (jointly with the liquidation of women's organizations attached to the party organizations), gender equality remained an unreachable dream even in the media discourse. The media discourse in 1930 s was a censored version of reality since it was about scrapping to all emancipation projects, displacement onto the margins from the public space of all feminist ideas but active promotion of patriarchic norms and values instead. Negative consequences of feminist movement closing-up in the USSR are felt also in modern Ukraine which has to go through this hard but a necessary way to build a society free from any indications of gender discrimination.

Experts say that the modern journalists intend to take previous experience into account and to correct the situation concerning the representation of women in media, but the content of the Ukrainian media is not still balanced in a gender aspect. That is why we consider further researches of this topical problem required and promising. 


\section{References}

Butler, J. (2016). Frames of war: When is life grievable? London: Verso.

Breaking Gender Stereotypes (2020). https://genderinmyanmarnews.org/en/publication/sources-andstereotypes

Fedotova, L.N. (2004). Sociology of Mass Communication: A Textbook for High Schools. Sankt-Peterburg: Piter.

Gender balance monitoring in Ukrainian online media (2019). https://imi.org.ua/monitorings/monitoryngove-doslidzhennya-gendernogo-balansu-v-ukrayinskyhonlajn-zmi-gruden-2019-i30940

Gender covert discrimination (2019). https://www.edcamp.org.ua/nondiscrimination.

Gill, R. (2009). Mediated intimacy and postfeminism: A discourse analytic examination of sex and relationships advice in a women's magazine. Discourse \& Communication, 3(4), 345-369. doi:10.1177/1750481309343870

Goffman, E (1976). Gender advertisements. London: The Society for the Study of Visual Communication.

Lazar, M. (2007) Feminist critical discourse analysis. Articulating a feminist discourse praxis. Critical Discourse Studies 4 (2): 141-164.

Malytskyi, F. Storming coal. The Globe. 1932. January. 2 (194): 17-18.

Matheson, D. (2017). Media discourse. Analysis of media texts. Media and culture research. Kharkov: Gumanitarnyi Centr.

McQuail, D. (2010) Theory of Mass Communication. Lviv: Litopys.

Romanov, P. \& Yarskaya-Smirnova, E. (2009) “Eye Soviet man”: rules of vision / suspicion. Visual anthropology: visibility modes under socialism. Moskva: Variant, TsSPGI, 7-17.

Sovenko O. (20017-2018) Gender Discourse in Contemporary Media (Based on Regional Monitoring Materials 2017-2018)]. https://genderindetail.org.ua/library/ukraina/genderniy-diskurs-u-suchasnihmedia-na-materialah-monitoringu-regionalnoi-presi-2017-2018-134487.html.

Voronina, M. (2017). Ukrainian women in the modernization chimney. Kharkiv, 78-106.

Zoonen van, L (1994). Feminist Media Studies. London: SAGE. 